\section{Comparison of Shank- and Drip-applied Methyl Bromide Alternatives in Perennial Crop Field Nurseries}

\author{
S.M. Schneider ${ }^{1}$, B.D. Hanson ${ }^{2,5}$, J.S. Gerik ${ }^{2}$, A. Shrestha ${ }^{3}$, \\ T.J. Trout ${ }^{4}$, and S. Gao ${ }^{2}$
}

ADDITIONAL INDEX WORDS. 1,3-dichloropropene, chloropicrin, iodomethane, methyl bromide, Meloidogyne, nematode, soilborne pathogens, fumigation

SuMMARY. Methyl bromide has been used extensively in open-field perennial crop nurseries to ensure the production of plants that are free of soilborne pests and pathogens. California regulations require that nursery stock for farm planting be commercially clean with respect to economically important nematodes. Under the terms of the Montreal Protocol, the use of methyl bromide by developed countries was phased out 1 Jan. 2005. Although the perennial nursery industry in the United States largely continues to use methyl bromide under critical use exemptions and quarantine/preshipment criteria allowed under provisions of the Montreal Protocol, nursery growers need viable alternatives to this fumigant. Two fumigation trials in perennial crop field nurseries with sandy loam and clay loam soils, respectively, were conducted to compare the efficacy of fumigants applied through standard shank-injection equipment or as emulsifiable compounds applied through drip irrigation equipment. In the garden rose (Rosa multiflora) nursery trial, nematodes were detected at planting in the untreated control, no-tarpaulin 1,3-dichloropropene + chloropicrin, and chloropicrin alone several months after treatment. Nematodes included root-knot nematode (Meloidogyne spp.) and stunt nematode (Tylenchorbynchus semipenetrans). At harvest 2 years later, root-knot nematode was detected in rose roots from untreated plots and plots treated with untarped 1,3-dichloropropene + chloropicrin, metam sodium, and chloropicrin alone. In the nut tree (Prunus spp.) nursery field trial, shank-injected treatments typically provided better nematode control than the same chemicals applied via the drip lines, although weed control and marketable trees were similar among treatments.

S oil fumigation with methyl bromide $(\mathrm{MB})$ has commonly been used before planting open-field perennial crop nurseries to meet

Sincere appreciation to N. Goodell, E. Levya, J. Gartung, and P. Neipp for technical support and to the Garden Rose Council, Jackson \& Perkins Roses, California Fruit Tree, Nut Tree, and Grapevine Improvement Advisory Board, Sierra Gold Nurseries, Tri-Cal, Arysta Life Science, Dow AgroSciences, Niklor, AmVac, and Cal-Agri for financial support and in-kind donations of chemicals, land, and plants.

This article is a U.S. government work and is in the public domain in the USA. Mention of a trademark, proprietary product, or vendor does not constitute a guarantee or warranty of the product by the U.S. Department of Agriculture and does not imply its approval to the exclusion of other products or vendors that also may be suitable.

${ }^{1}$ National Program Staff, U.S. Department of Agriculture, Agricultural Research Service, Crop Production and Protection, Beltsville, MD 20705

${ }^{2}$ U.S. Department of Agriculture, Agricultural Research Service, San Joaquin Valley Agricultural Sciences Center, 9611 S. Riverbend Avenue, Parlier, CA 93648

${ }^{3}$ California State University, Fresno, 2415 E. San Ramon Avenue M/S AS 72, Fresno, CA 93740

${ }^{4}$ U.S. Department of Agriculture, Agricultural Research Service, Fort Collins, CO 80526

${ }^{5}$ Corresponding author. E-mail: brad.hanson@ars. usda.gov. grower expectations and government regulations designed to ensure highquality planting stock for domestic and international markets. Fruit and nut nursery trees for planting into commercial orchards and vineyards in California must meet a regulation that states it is "mandatory that nursery stock for farm planting be commercially clean with respect to economically important nematodes" [California Department of Food and Agriculture (CDFA), 2002]. This regulation ensures that plant parasitic nematodes and soilborne pathogens are not spread from infested field nurseries and that establishment and vigor of new fruiting fields is not compromised. Garden roses are not usually planted into commercial settings and, therefore, are not required by the state of California to meet these regulations. However, other states and countries accept the California certification program as sufficient to meet their phytosanitary requirements, thus making certification critical to interstate and international marketing of garden rose nursery stock.

The nursery production cycle for garden roses and trees is usually 1 or 2 years in duration. Plants can be grown on their own roots or can be grafted or budded onto a desired rootstock. A common production rotation includes a l-year fallow or cover crop, 1 or 2 years of rotational crops, and a 1- or 2-year nursery crop. A cutting or seed is planted in winter and, in some cases, budded the following spring. The plants are harvested in the winter 1 or 2 years after planting and after the industry standard size and quality has been achieved. Garden rose and fruit/nut trees are subject to infection by a number of soilborne pests, including pathogens such as Pythium spp. and Verticillium dablia; nematodes such as lesion nematode (Pratylenchus spp.), root-knot nematode, and dagger nematode (Xiphinema spp.); and competition from a wide range of weeds (Johnson et al., 1969; Karlik et al., 2001; Santo and Lear, 1976; Voisin et al., 1995).

The standard treatment for compliance with California nursery regulations for clean planting stock in open-field nurseries is to shank-inject 300 to $400 \mathrm{lb} /$ acre a.i. of $98 \% \mathrm{MB}$ plus $2 \%$ chloropicrin (Pic) covered with high-density polyethylene (HDPE) tarpaulins. The MB component of this treatment provides

\begin{tabular}{llll}
\hline $\begin{array}{l}\text { Units } \\
\text { To convert U.S. to SI, } \\
\text { multiply by }\end{array}$ & U.S. unit & SI unit & $\begin{array}{l}\text { To convert SI to U.S., } \\
\text { multiply by }\end{array}$ \\
\hline 29.5735 & $\mathrm{fl} \mathrm{oz}$ & $\mathrm{mL}$ & 0.0338 \\
0.3048 & $\mathrm{ft}$ & $\mathrm{m}$ & 3.2808 \\
3.7854 & gal & $\mathrm{L}$ & 0.2642 \\
2.54 & inch(es $)$ & $\mathrm{cm}$ & 0.3937 \\
16.3871 & inch & $\mathrm{cm}^{3}$ & 0.0610 \\
1.1209 & lb/acre & $\mathrm{kg}^{3} \cdot \mathrm{ha}^{-1}$ & 0.8922 \\
1 & micron & $\mu \mathrm{m}$ & 1 \\
25.4 & mil & $\mu \mathrm{m}$ & 0.0394 \\
28.3495 & $\mathrm{oz}$ & $\mathrm{g}$ & 0.0353
\end{tabular}


consistent, effective control of nematodes, fungi, and weeds over a wide range of soil textures, soil moistures, and soil temperatures while the low rate of Pic serves primarily as a warning agent. HDPE tarps are used to increase pest control efficacy by slowing the rate of fumigant diffusion from the soil to the atmosphere. MB is an ozone-depleting compound and has been phased out under the terms of the Montreal Protocol, an international treaty (United Nations Environment Programme, 1999). After 1 Jan. 2005, any use of MB by a developed country was required to: 1) meet the criteria of an approved critical use exemption (CUE), 2) meet the criteria of quarantine/preshipment (QPS) use, or 3) be from MB stocks that existed before 1 Jan. 2005. Currently, under CUE and QPS exemptions, $\mathrm{MB}$ remains the most commonly used soil treatment for certified nursery production in California. Growers of perennial nursery crops need alternatives to $\mathrm{MB}$ to produce high-quality plants that meet clean planting material requirements. Compared with $\mathrm{MB}$, many potential alternatives provide consistent control over a narrower spectrum of pests and pathogens and are more sensitive to soil conditions (Duniway, 2002). For some California nurseries with sandy soils, 1,3-dichloropropene $(1,3-D)$ is an approved treatment for certified nursery stock (CDFA, 2002); however, maximum rates are not sufficient to provide adequate pest control in nurseries with finetextured soil. Use of 1,3-D in California nurseries is further restricted by township caps, which limit the amount that can be used in each township (California Department of Pesticide Regulation, 2002). This cap is shared by all $1,3-\mathrm{D}$-using crops in a township on a first-come, first-served basis. Metam-sodium and Pic are currently registered in the United States and have provided nematode, pathogen, or weed control in trials in various production systems (De Cal et al., 2004; Gilreath et al., 2005; Karlik et al., 2001; Mann et al., 2005), but are not currently approved for certified nursery production in California. Iodomethane (IM), which is not yet registered in California but has a limited registration in other states, has shown promise in openfield nursery trials, as well as other cropping systems (Becker et al., 1998; Eayre et al., 2000; Lampinen et al., 2005; Schneider et al., 2005).

Soil fumigants have traditionally been injected into the soil by pressure through tractor-mounted shanks or as hot gas through buried drip lines. Emulsified formulations of 1,3-D and Pic designed for water delivery of fumigants through drip irrigation systems have recently been registered in the United States and are quickly being adopted in bedded strawberry (Fragaria Xananassa) and floriculture production in California (Ajwa and Trout, 2004; Gerik, 2005). Grapevine (Vitus vinifera) open-field nursery trials with drip-applied materials containing 1,3-D demonstrated good nematode control (Schneider et al., 2004).

The objective of the trials reported here was to evaluate registered and experimental alternatives to $\mathrm{MB}$ in open-field nurseries. The evaluations compared shank- and dripapplied materials for effects on nematodes, weeds, and production of marketable nursery plants.

\section{Materials and methods}

General. Field trials were initiated in commercial garden rose and nut tree nurseries in 2001 and 2004, respectively. The preplant fumigation experiments were similar at the two locations, although specific cropping practices varied between the nurseries (Table 1). In the 2001 trial, a standard MB:Pic treatment was compared with three shank-applied and eight drip-applied alternatives, while in the 2004 trial, the experimental treatments were reduced to three shankand three drip-applied alternatives (Table 2). Because treatments were chosen to represent current best management recommendations at the time, formulations and rates varied slightly between the two trials.

Fumigant application. In the 2001 garden rose nursery trial, each treatment was replicated six times and individual plot size was $11 \times 100 \mathrm{ft}$ and $11 \times 50 \mathrm{ft}$ for the shank-injected and drip-applied treatments, respectively (Table 2). The shank-injected treatments were applied using commercial application equipment on 31 Aug. 2001 (TriCal, Hollister, CA). The three tarpaulin-covered (tarped) treatments were applied with a Noble plow rig (10-inch injection depth, 12-inch nozzle spacing) equipped to inject fumigant and install l-mil HDPE film in a single operation. The 1,3-D:Pic with no tarpaulin (untarped) treatment was applied with a Telone rig (18-inch injection depth, 20-inch nozzle spacing) and the soil surface was compacted to seal the plots after injection. The tarpaulins were removed $7 \mathrm{~d}$ after the fumigant application.

Field preparation for dripapplied treatments began in midSept. 2001 after the field was safe for reentry and nursery operations resumed. Planting beds (4-ft spacing, three beds per plot) were formed and thin-walled drip irrigation tubes (drip tape) with $0.25 \mathrm{gal} / \mathrm{h}$ emitters spaced 12 inches apart (T-Tape TSX 50812-450; T-Systems International, San Diego, CA) were installed 12 inches deep. Drip tubes were placed in the center of the bed and in the furrow (24-inch spacing) to obtain a broadcast treatment over the entire plot. The irrigation delivery system was designed to minimize pressure variation and to achieve distribution uniformity greater than $90 \%$. The fumigants were applied over $12 \mathrm{~h}$ on 3 and 4 Oct. 2001 in 2.5 inches of irrigation water, with the amount of water expected to penetrate to a depth of 48 inches based on soil texture and soil water content at the time of fumigation. The fumigant was delivered from pressurized cylinders through a manifold and into the drip lines using the method described by Ajwa et al. (2002). At the completion of each drip treatment, $1 / 2$ inch of water was applied through overhead sprinklers to seal the soil surface. Seven days after the initial drip treatments, the second half of the Pic-split treatment was applied in $1-1 / 4$ inches of water.

In the 2004 nut tree nursery trial, each treatment was replicated five times and individual plot size was 23 $\times 100 \mathrm{ft}$ and $23 \times 50 \mathrm{ft}$ for the shankinjected and drip-applied treatments, respectively. Shank treatments were applied on 10 Sept. 2004 using the previously described Noble plow rig to inject and tarp the MB:Pic and IM:Pic 67:33 treatments. The 1,3D-shank and 1,3-D:Pic treatments were applied using the previously described Telone rig. Following fumigant application, the 1,3-D plots were sealed using a tandem disk and ring 
Table 1. Field history, soil properties, application information, and nursery crop in two perennial crop field nursery fumigation trials near Wasco, CA, in 2001-03 and Yuba City, CA, in 2004-06.

\begin{tabular}{|c|c|c|}
\hline Nursery information & $\begin{array}{c}2001 \text { Garden } \\
\text { rose nursery trial }\end{array}$ & $\begin{array}{l}2004 \text { Nut tree } \\
\text { nursery trial }^{\mathrm{z}}\end{array}$ \\
\hline Location & Wasco, CA & Yuba City, CA \\
\hline Soil type & $\begin{array}{l}\text { Wasco sandy } \\
\text { loam }\end{array}$ & $\begin{array}{l}\text { Conejo clay } \\
\text { loam }\end{array}$ \\
\hline Organic matter $(\%)$ & 0.7 & 2.2 \\
\hline $\mathrm{pH}$ & 6.8 & 7.1 \\
\hline Sand:silt:clay (\%) & $72: 16: 12$ & $19: 51: 30$ \\
\hline Cropping history & $\begin{array}{l}\text { Rose nursery/row } \\
\text { crop rotation }\end{array}$ & $\begin{array}{l}\text { Old pear } \\
\text { orchard/new nursery }\end{array}$ \\
\hline Previous crop & 'Nemex' cotton & Pear \\
\hline Previous crop removed & August 2001 & Spring 2002 \\
\hline Break crop & None & $\begin{array}{l}\text { Two winter } \\
\text { wheat crops }\end{array}$ \\
\hline \multicolumn{3}{|l|}{ Fumigation } \\
\hline Shank-applied treatments & 31 Aug. 2001 & 10 Sept. 2004 \\
\hline Drip-applied treatments & 3 and 4 Oct. 2001 & 11 Sept. 2004 \\
\hline $\begin{array}{l}\text { Soil moisture } \\
\qquad \% \mathrm{w} / \mathrm{w}) \text { at } 12,24,36, \\
48, \text { and } 60 \text { inches, } \\
\text { respectively }^{\mathrm{y}}\end{array}$ & $10.5,9.4,8.4,12.7,14.9$ & $17.017 .2,19.9,21.6,22.9$ \\
\hline Nursery crop rootstock & 'Dr. Huey' rose & 'Lovell' peach \\
\hline Planting date & November 2001 & November 2004 \\
\hline $\begin{array}{l}\text { Budding date/scion } \\
\text { variety }\end{array}$ & Unbudded & $\begin{array}{l}\text { May } 2005 / \text { 'Nonpareil' } \\
\text { almond }\end{array}$ \\
\hline Harvest date & December 2003 & January 2006 \\
\hline
\end{tabular}

${ }^{2}$ Rose (Rosa multiflora), cotton (Gosyypium hirsutum), pear (Pyrus calleryana), wheat (Triticum aestivum), peach (Prunus persica), and almond (Prunus dulcis).

${ }^{y} 1$ inch $=2.54 \mathrm{~cm}$.

roller to compact the soil, and HDPE was installed using the Noble plow rig with the injection shanks removed.

Drip lines in the nut tree nursery trial were buried 8 inches deep and 24 inches apart to provide a broadcast application of the fumigants, and the Noble plow, with shanks removed, was used to install HDPE on the plots. Drip treatments $(4-1 / 3$ inches of water applied over a $21-\mathrm{h}$ period) were applied on 11 Sept. 2004 using the previously described system.

Crop production. The garden rose and nut tree nursery crops were managed by the cooperating nurseries according to standard commercial practices for planting, fertilization, in-season tillage, budding, and harvest preparations (Table 1). Hardwood cuttings of the rose rootstock 'Dr. Huey' were planted on the bed tops in late Nov. 2001 and the field was irrigated with sprinklers to seal the soil surface and set the cuttings firmly in the planting bed. In the garden rose trial, the crop was not budded to a commercial scion variety, and all vigor evaluations were made on the rootstock. In the nut tree nursery, 'Lovell' peach (Prunus persica) seed was planted in Nov. 2004. After germinating and reaching sufficient size, the peach rootstock was budded with 'Nonpareil' almond (Prunus dulcis) in May 2005. Irrigation water in both trials was applied through the subsurface drip tubing. Although drip irrigation is not widely used in the perennial crop nursery industry, this method was chosen to avoid potential movement of soilborne pests among plots with the more commonly used furrow or sprinkler irrigation systems. Bare-root nursery stock from the center row of each plot was harvested using a singlerow tree harvester in Dec. 2003 and Jan. 2006 in the garden rose and nut tree nursery trials, respectively.

DATA COLLECTION: GARDEN ROSE TRIAL. In the garden rose trial, control of native nematode populations was determined at planting in Nov. 2001 and again in March and Nov. 2003 [16 and 24 months after planting (MAP)]. The Nov. 2001 soil samples were collected with a 3 -inch-diameter bucket auger from the center of each plot in 12-inch increments to a depth of $5 \mathrm{ft}$. Soil samples were thoroughly mixed and a $250 \mathrm{~cm}^{3}$ subsample was extracted using the sieving/Baermann funnel protocol that recovers only those nematodes that could reasonably be assumed to still be viable as plant parasites (Barker, 1985; Flegg and Hooper, 1970). The 16 and 24 MAP soil samples were collected with a 1 -inch-diameter sampling tube to a depth of 24 inches. Ten soil cores were collected from the middle row of each plot, thoroughly mixed, and the nematodes were extracted from a $250-\mathrm{cm}^{3}$ subsample using the sieving/sugar flotation/centrifugation protocol with a 500 -mesh sieve (25$\mu \mathrm{m}$ opening) (Barker, 1985; Jenkins, 1964). The nematodes in each sample were identified and counted under a microscope, and the data were standardized to a $100-\mathrm{cm}^{3}$ subsample.

At planting, soil was collected from the upper 12 inches of each plot using a l-inch-diameter sampling tube for assaying populations of two representative soil pathogens. Soil cores from each plot were thoroughly mixed and a subsample was assayed for populations of Pythium spp. by dilution plating ( $1 \mathrm{~g}$ of soil in $10 \mathrm{~mL}$ of sterile water; $0.5 \mathrm{~mL}$ on each of five replicated plates, incubated at room temperatures for $48 \mathrm{~h}$ ) on Martin's medium (Martin, 1992), and for $V$. dabliae using the method of Huisman and Ashworth (1974). Pythium spp. can be root and stem rot pathogens under moist conditions and can also serve as a general indicator of treatment effect on oomycetes, while $V$. dabliae can cause severe wilt in many ornamentals species, including garden rose (Dreistadt, 2001).

Weed control and plant vigor in the garden rose nursery trial was evaluated in Mar. 2002 and 2003 (4 and $16 \mathrm{MAP}$ ). Weed pressure was scored on a 0 (no weeds observed) to 5 (solid mat of weeds in the plant row) scale. Plant vigor was scored on a 0 (dead plants) to 5 (vigorous growth).

Twenty-five rose plants from the middle of the center row in each plot were evaluated for plant vigor and quality at harvest in Dec. 2003. The number of canes on each plant and the diameter of each cane were determined. Root samples were collected from plants harvested from the middle 
Table 2. Shank- and drip-applied fumigant treatments in a 2001-03 garden rose nursery trial near Wasco, CA, and a 2004-06 nut tree field nursery trial near Yuba City, CA.

\begin{tabular}{|c|c|c|c|c|}
\hline$\underline{\text { Treatment }}$ & Chemical & $\begin{array}{c}\text { Active ingredient } \\
(\%)\end{array}$ & $\begin{array}{c}\text { Rate } \\
(\text { lb/acre a.i. })^{y}\end{array}$ & Application method ${ }^{\mathrm{z}}$ \\
\hline \multicolumn{5}{|c|}{2001 Garden rose nursery treatments } \\
\hline MB:Pic & Methyl bromide:chloropicrin & $98: 2$ & 350 & Shank (Noble plow), HDPE tarp \\
\hline IM:Pic 30/70 & Iodomethane:chloropicrin & $30: 70$ & 400 & Shank (Noble plow), HDPE tarp \\
\hline 1,3-D:Pic & 1,3-Dichloropropene:chloropicrin & $61: 35$ & 515 & Shank (Noble plow), HDPE tarp \\
\hline 1,3-D-drip & 1,3-Dichloropropene & 94 & 332 & Drip, no tarp \\
\hline IM:Pic 30/70 & Iodomethane:chloropicrin & $29: 68$ & 400 & Drip, no tarp \\
\hline IM:Pic 50/50 & Iodomethane:chloropicrin & $48: 48$ & 300 & Drip, no tarp \\
\hline Metam-na & Sodium methyldithiocarbamate & 42 & 320 & Drip, no tarp \\
\hline Pic-low & Chloropicrin & 99 & 200 & Drip, no tarp \\
\hline Untreated & - & - & - & - \\
\hline MB:Pic & Methyl bromide:chloropicrin & $98: 2$ & 400 & Shank (Noble plow), HDPE tarp \\
\hline IM:Pic $67 / 33$ & Iodomethane:chloropicrin & $67: 33$ & 300 & Shank (Noble plow), HDPE tarp \\
\hline 1,3-D:Pic & 1,3-Dichloropropene:chloropicrin & $61: 35$ & 515 & Shank (Telone rig), HDPE tarp \\
\hline 1,3-D-shank & 1,3-Dichloropropene & 98 & 332 & Shank (Telone rig), HDPE tarp \\
\hline IM:Pic $67 / 33$ & Iodomethane:chloropicrin & $67: 33$ & 300 & Drip, HDPE tarp \\
\hline 1,3-D:Pic-drip & 1,3-Dichloropropene:chloropicrin & $61: 33$ & 515 & Drip, HDPE tarp \\
\hline 1,3-D-drip & 1,3-Dichloropropene & 94 & 332 & Drip, HDPE tarp \\
\hline
\end{tabular}

${ }^{2}$ The Noble plow rig was set up to inject fumigants at a 10 -inch $(25.4 \mathrm{~cm})$ depth through nozzles spaced 12 inches $(30.5 \mathrm{~cm})$ apart while simultaneously installing a 1 -mil $(25.4$ $\mu \mathrm{m})$ high-density polyethylene (HDPE) tarp. The Telone rig was set up to inject fumigants at an 18 -inch $(45.7 \mathrm{~cm})$ depth through curved shanks spaced 20 inches $(50.8 \mathrm{~cm})$ apart and the soil was compacted after fumigant injection to reduce emissions. Drip-applied treatments used fumigants formulated as emulsifiable concentrates and applied with irrigation water through a system of buried drip tapes with emitters at 12 -inch intervals. If HDPE tarp was installed on plots treated with the Telone rig or with drip application equipment, the tarp was installed using the Noble plow rig with the shanks removed.

l $\mathrm{lb} /$ acre $=1.1209 \mathrm{~kg} \cdot \mathrm{ha}^{-1}$.

row of each plot. Root samples were thoroughly mixed and the nematodes were extracted from a 20 -g subsample using the mist chamber protocol for 5 d (Barker, 1985).

Data Collection: NUT TREe TRIAL. Data collection procedures in the 2004 nut tree nursery trial differed slightly from the garden rose nursery trial due to cropping system differences. Before fumigation, soil samples were collected with a 3inch-diameter bucket auger from the center of each plot in 12 -inch increments down to a depth of $5 \mathrm{ft}$ and the nematodes were extracted as previously described. Because of relatively low populations of native nematodes at this site, fumigation efficacy was determined by burying muslin bags containing $100 \mathrm{~g}$ of soil infested with citrus nematode (Tylenchulus semipenetrans) at 6-, 12-, 24-, and 36-inch depths in the center of each plot. Nematode bags were recovered 1 month after fumigation and were processed using the sieving/Baermann funnel pro- tocol. Nematodes were identified and counted under the microscope. Native nematode population density in the upper 12 inches of each plot was determined 9 MAP near the end of the production cycle. Soil samples were collected with 1 -inch-diameter sampling tubes and samples were processed using the sieving/sugar flotation/centrifugation protocol.

Weed control was determined in Mar. 2005 by counting and identifying all weeds in a $1.5 \times 50$ - $\mathrm{ft}$ area in a single, randomly chosen row in each plot. Weed counts were taken before any tillage or handweeding operation and before the rootstock was budded to almond. Tree vigor was determined in Dec. 2005 by measuring trunk caliper 3 inches above the bud union of 25 trees from the center of each plot.

All trees from the center 50-ft row were harvested by the cooperating grower in Jan. 2006. Trees from each plot were commercially graded, sorted by size class, and culled, if necessary, according to market standards. Root samples were collected from random plants in each harvested row and the nematodes were extracted from a 20 g subsample using the mist chamber protocol.

Statistical analysis. Both experiments were designed as randomized complete blocks with five or six replications. Nematode counts were transformed using $[\ln (\mathrm{x}+\mathrm{l})]$ to stabilize the variance (Noe, 1985); however, data presented are antilogs of the means. Nematode control, weed control, plant vigor, and harvest data were analyzed using analysis of variance (ANOVA) and treatment means were separated by Fisher's protected least significant difference procedure at $P<0.05$ (SAS version 9.1; SAS Institute, Cary, NC).

\section{Results and discussion}

GARDEN ROSE FIELD NURSERY TRIAL. Fairly low populations of the stunt nematode (Table 3 ), and very low populations of root-knot nematode and stubby root nematode 
Table 3. Control of stunt nematode and root-knot nematode in a garden rose nursery fumigation trial near Wasco, CA, in $2001-03 .^{2}$

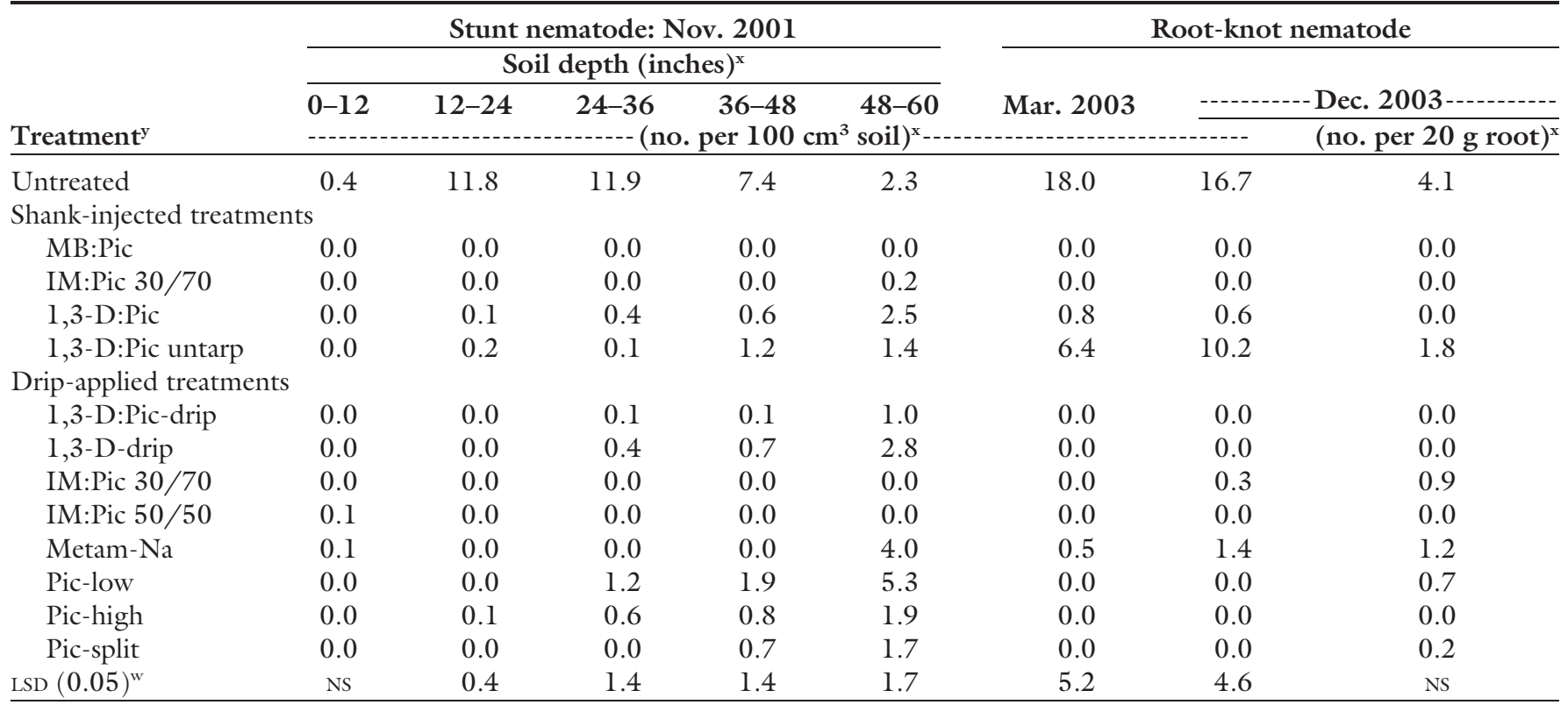

${ }^{2}$ Statistical analyses on nematode population was conducted on $\log$ transformed $[\ln (n+1)]$ data; however, data presented are the antilogs of the means.

yTreatments are detailed in Table 2 . The 2001 trial included four treatments applied with tractor-mounted shank equipment [ $\mathrm{MB}:$ Pic $=98 \%$ methyl bromide:2\% chloropicrin at $350 \mathrm{lb} /$ acre; IM:Pic 30/70 = 30\% iodomethane:70\% chloropicrin at $400 \mathrm{lb} /$ acre; 1,3 -D:Pic $=61 \% 1,3$-dichloropropene:35\% chloropicrin at $515 \mathrm{lb} /$ acre each covered with high-density polyethylene (HDPE) tarp; 1,3-D:Pic untarped = 61\% 1,3-dichloropropene:35\% chloropicrin at $515 \mathrm{lb} /$ acre with no HDPE tarp ] and eight untarped treatments applied through a drip irrigation system [1,3-D:Pic - drip = 61\% 1,3-dichloropropene:33\% chloropicrin at $515 \mathrm{lb} / \mathrm{acre}$; 1,3 -D-drip = 94\% 1,3 -dichloropropene at 332 lb/acre; IM:Pic $30 / 70=29 \%$ iodomethane: $68 \%$ chloropicrin at $400 \mathrm{lb} /$ acre; IM:Pic $50 / 50=48 \%$ iodomethane: $48 \%$ chloropicrin at $300 \mathrm{lb} /$ acre; metam-na $=42 \%$ sodium methyldithiocarbamate at $320 \mathrm{lb} / \mathrm{acre} ; 99 \%$ chloropicrin at $200 \mathrm{lb} /$ acre (Pic-low), $400 \mathrm{lb} / \mathrm{acre}$ (Pic-high), and a split application of $200 \mathrm{lb} / \mathrm{acre}$ applied twice $7 \mathrm{~d}$ apart (Picsplit)]; l lb/acre $=1.1209 \mathrm{~kg} \cdot \mathrm{ha}^{-1}$

${ }^{x} 1$ inch $=2.54 \mathrm{~cm}, 1$ nematode $/ 100 \mathrm{~cm}^{3}=0.1639$ nematode $/$ inch $^{3}, 1$ nematode $/ 20 \mathrm{~g}=1.4175$ nematode $/ \mathrm{oz}$.

"Fisher's protected least significant difference procedure at $P<0.05 ; \mathrm{NS}=$ nonsignificant.

[Paratrichodorus spp. (data not shown)] were found in the samples collected from untreated plots at the time of planting. The low root-knot nematode population was expected following the root-knot nematoderesistant cotton (Gossypium hirsutum) crop. No plant parasitic nematodes were found at any soil depth in the MB:Pic-treated plots at planting (Table 3 ). All other chemical treatments provided control statistically comparable to MB:Pic in the top 36 inches of soil, although nematodes were detected in some samples. In the 36- to 48-inch soil depth, plant parasitic nematodes were not detected in the MB:Pic, shank- or drip-applied IM:Pic, and metam sodium-treated plots. 1,3-D:Pic; 1,3-D:Pic-drip; 1,3-D-drip; and split and high rates of Pic were not significantly different from MB:Pic, even though nematodes were detected. Plots treated with $200 \mathrm{lb} /$ acre rate of Pic (Pic-low) had more nematodes than the MB:Pic plots and fewer than the untreated control at 36 to 48 inches. At the 48 - to 60-inch depth, nematode populations were below detectable levels in the MB:Pic and drip-applied
IM:Pic plots. All other treatments were similar $(P>0.05)$ to the untreated control in the deepest soil depths evaluated.

Pythium spp. propagules were found in the top 24 inches in all treatments except shank-injected IM:Pic (Table 4). All chemical treatments significantly reduced Pythium propagules compared with the untreated control and were not different from each other. $V$. dabliae was not found in any sample (data not shown).

Weed control 4 MAP was comparable to MB:Pic in shank-injected and drip-applied IM:Pic; tarped 1,3D:Pic; 1,3-D:Pic-drip; and the 400 $\mathrm{lb} /$ acre rate of Pic (Pic-high) (Table 4). Weed control in plots treated with untarped 1,3-D:Pic; 1,3-D-drip; metam-sodium; and the low rate of Pic was not different from untreated plots. The split treatment of Pic provided intermediate weed control. Covering the shank-applied 1,3D:Pic treatment with HDPE film clearly improved weed control, and it is likely that weed control in drip 1,3-D:Pic treatments would also have benefited from a tarpaulin. While installing HDPE film before dripapplication of fumigants in plastic mulch/bedded crops such as strawberry is a normal practice, the logistics and expense of using tarpaulins over a broadcast arrangement of drip tubes makes this alternative difficult in open-field nurseries. The addition of an herbicide to the management system might be required, but extra care must be used when selecting an herbicide for a nursery cropping system to avoid any phytotoxicity, above- or belowground, because the marketable product is a bare-root plant (Hanson and Schneider, 2008). Plant vigor, $4 \mathrm{MAP}$, did not vary significantly across treatments, although the least vigorous usually were in the untreated control (Table 4).

At the beginning of the second growing season, Mar. 2003, rootknot nematode was detected in the untreated and the untarped 1,3-D:Pic plots (Table 3 ). Nematodes were detected in the tarped 1,3-D:Pic and the metam sodium plots, although these treatments were not significantly greater than the nondetectable population in the MB:Pic plots. As expected, root-knot nematode populations that 
Table 4. Pythium populations, weed control, and plant vigor in a commercial garden rose nursery trial near Wasco, CA, in 2001-03.

\begin{tabular}{|c|c|c|c|c|c|}
\hline \multirow[b]{3}{*}{ Treatment $^{\mathrm{z}}$} & \multirow{3}{*}{$\begin{array}{c}\frac{\text { Pythium propagules }}{\text { Nov. } 2001} \\
{\text { (no./g soil })^{\mathrm{y}}}^{\text {no. }} \\
\end{array}$} & \multicolumn{2}{|c|}{ Weed control index } & \multicolumn{2}{|c|}{ Plant vigor index } \\
\hline & & Mar. 2002 & Mar. 2003 & Mar. 2002 & Mar. 2003 \\
\hline & & \multicolumn{2}{|c|}{$(1-5 \text { scale })^{x}$} & \multicolumn{2}{|c|}{$(1-5 \text { scale })^{\mathrm{w}}$} \\
\hline \multicolumn{6}{|c|}{ Shank-injected treatments } \\
\hline MB:Pic & 3 & 0.5 & 0.8 & 4.5 & 4.0 \\
\hline IM:Pic $30 / 70$ & 0 & 1.2 & 2.0 & 3.8 & 3.8 \\
\hline \multicolumn{6}{|c|}{ Drip-applied treatments } \\
\hline 1,3-D:Pic-drip & 7 & 1.0 & 2.3 & 3.8 & 4.0 \\
\hline 1,3-D-drip & 57 & 2.8 & 3.0 & 3.2 & 3.5 \\
\hline IM:Pic 30/70 & 77 & 1.5 & 2.3 & 4.2 & 3.5 \\
\hline IM:Pic 50/50 & 133 & 1.5 & 3.8 & 4.2 & 3.3 \\
\hline Metam-Na & 33 & 3.0 & 4.0 & 3.8 & 2.5 \\
\hline $\operatorname{LSD}(0.05)^{\mathrm{v}}$ & 186 & 1.9 & 2.4 & NS & 1.1 \\
\hline
\end{tabular}

${ }^{2}$ Treatments are detailed in Table 2. The 2001 trial included four treatments applied with tractor-mounted shank injection equipment $[\mathrm{MB}:$ Pic $=98 \%$ methyl bromide: $\%$ chloropicrin at $350 \mathrm{lb} /$ acre; IM:Pic $30 / 70=30 \%$ iodomethane:70\% chloropicrin at $400 \mathrm{lb} /$ acre; 1,3 -D:Pic $=61 \% 1,3$-dichloropropene:35\% chloropicrin at $515 \mathrm{lb} /$ acre each covered with high-density polyethylene (HDPE) tarp; 1,3-D:Pic untarped = 61\% 1,3-dichloropropene:35\% chloropicrin at $515 \mathrm{lb} /$ acre with no HDPE tarp] and eight untarped treatments applied through a drip irrigation system [1,3-D:Pic-drip $=61 \% 1,3$-dichloropropene:33\% chloropicrin at $515 \mathrm{lb} /$ acre; 1,3 -D-drip $=94 \% 1,3$ dichloropropene at $332 \mathrm{lb} /$ acre; IM:Pic $30 / 70=29 \%$ iodomethane: $68 \%$ chloropicrin at $400 \mathrm{lb} /$ acre; IM:Pic $50 / 50=48 \%$ iodomethane:48\% chloropicrin at $300 \mathrm{lb} /$ acre; metam-na $=42 \%$ sodium methyldithiocarbamate at $320 \mathrm{lb} /$ acre; $99 \%$ chloropicrin at $200 \mathrm{lb} / \mathrm{acre}$ (Pic-low), $400 \mathrm{lb} / \mathrm{acre}(\mathrm{Pic}-\mathrm{high})$, and a split application of $200 \mathrm{lb} / \mathrm{acre}$ applied twice $7 \mathrm{~d}$ apart (Pic-split)]; l lb/acre $=1.1209 \mathrm{~kg} \cdot \mathrm{ha}^{-1}$

Fungal populations were determined in soil samples collected to a depth of 24 inches $(61.0 \mathrm{~cm}) ; 1$ propagule $/ \mathrm{g}=28.3495 \mathrm{propagules} / \mathrm{oz}$.

${ }^{x} 0$ to 5 scale where $0=$ no visible weeds and $5=$ solid mat of weeds in plant row

${ }^{w} 0$ to 5 scale where $0=$ all plants dead and $5=$ robust plant growth.

v Fisher's protected least significant difference procedure at $P<0.05$; NS $=$ nonsignificant.

were reduced to nearly undetectable levels by the use of the root-knot nematode-resistant cotton in the rotation recovered to low but detectable population levels before the second growing season. These results confirm that "undetectable" does not always mean zero population and that $\mathrm{MB}$ alternatives need to be evaluated over the full cropping cycle.

Weed control at the beginning of the second growing season was greatest in the MB:Pic and tarped 1,3-D:Pic plots and was least in the untreated, IM:Pic 50/50, and metam-sodium treatments (Table 4). All other treatments were intermediate in weed control and varied greatly among replications $(P>0.05)$. The value of the tarp with the 1,3D:Pic-shank treatments for weed control was still evident. Plant vigor at the start of the second growing season was greatest in the MB:Pic; tarped 1,3-D:Pic; 1,3-D:Pic-drip; and high rate of Pic, and was least in the untreated plots (Table 4). Lack of vigor in the untreated plots likely was a response to the combination of soilborne pathogens, nematodes, and weed competition.
At harvest in Dec. 2003, root-knot nematode populations were greatest in the untreated and untarped 1,3D:Pic plots (Table 3). Several other treatments had low, but still detectable, populations of root-knot nematode that would be unacceptable in a certified nursery crop.

Plant vigor at harvest was determined by counting the number of canes in each of three size categories: diameter less than or equal to $1 / 4$ inch, diameter between $1 / 4$ and $3 / 8$ inch, and diameter greater than or equal to $3 / 8$ inch. These correspond to industry standards that determine the grade of each plant based on the number of canes in each category. Compared with MB:Pic, metamsodium and split Pic plots had fewer total canes per plant (data not shown). The highest number of large canes was found in plots treated with MB:Pic; 1,3-D:Pic-drip; and IM:Pic $50 / 50$. The smallest number of large canes occurred in the untreated controls and metam sodium-treated plots. No phytotoxicity was observed in any treatment (data not shown).

NUT TREE FIELD NURSERY TRIAL. Control of citrus nematode in the nut tree nursery trial was better than the untreated control and was statistically similar to MB:Pic with all treatments at all depths except for 1,3-D-drip at 36 inches (Table 5 ). However, several treatments did not provide a commercially acceptable level of control at deeper depths in the soil. Poor control was most evident with shankapplied 1,3-D:Pic at 36 inches and drip applications of IM:Pic 67/33 at 36 inches; 1,3-D:Pic-drip at 24 and 36 inches; and 1,3-D-drip at all soil depths. Native nematode populations were very low 11 months after treatment. Dagger nematode was only found in three of five untreated plots, while stunt nematode was found at low but detectable levels in all dripapplied treatments and in the shankapplied 1,3-D-shank treatment.

Weed control was evaluated in the spring when the majority of weeds present were volunteer wheat (Triticum aestioum) and california burclover (Medicago hispida). Volunteer wheat populations were lower in all treated plots compared with the untreated control and were similar among fumigation treatments (Table 6). Conversely, the amount of california 
burclover was slightly higher than the control in most of the fumigated plots. Germination stimulation by fumigants in hard-seeded weeds has been previously reported and may be due to seedcoat scarification in the treated plots (Horowitz and Taylorson, 1985; Martin, 2003; Motis and Gilreath, 2002). There were no biologically significant differences among treatments in preharvest caliper measurements, likely due to the large variability commonly found in a row of nursery stock (data not shown).

Total marketable almond trees were similar for the MB:Pic treatment and the untreated control (Table 6). The 1,3-D-shank plots had more marketable trees than the untreated control and drip-applied 1,3-D-drip and IM:Pic 67/33. There were no differences among treatments for number of trees in the smallest (less than $3 / 8$ inch diameter) and largest (greater than $5 / 8$ inch diameter) size classes. In the two intermediate size classes, there were small statistical differences among treatments, although this may not represent an economic impact because total trees in the range of $3 / 8$ to $5 / 8$ inch diameter did not differ among treatments. For example, the MB:Pic treatment had significantly more $3 /$ 8 - to $1 / 2$-inch-diameter trees compared with the untreated control, but only 1,3-D-shank and 1,3-D-drip had more $1 / 2$ - to $5 / 8$-inch-diameter

Table 5. Nematode $\operatorname{control}^{\mathrm{z}}$ in a nut tree nursery fumigation trial near Yuba City, CA, in 2004-06. Bags containing citrus nematode-contaminated soil were buried at four depths in each plot before fumigation and were recovered 1 month later. Native nematode populations in the top 12 inches $(30.5 \mathrm{~cm})$ of soil were determined 9 months after planting. ${ }^{z}$

\begin{tabular}{|c|c|c|c|c|c|c|}
\hline \multirow[b]{3}{*}{ Treatment $^{\mathrm{y}}$} & \multicolumn{4}{|c|}{$\begin{array}{c}\text { Citrus nematode } \\
\text { survival (soil depth in inches) }{ }^{\mathrm{x}}\end{array}$} & \multicolumn{2}{|c|}{$\begin{array}{c}\text { Native nematode } \\
\text { population }\end{array}$} \\
\hline & 6 & 12 & 24 & 36 & Dagger & Stunt \\
\hline & \multicolumn{6}{|c|}{ (no. per $100 \mathrm{~cm}^{3}$ soil $)^{\mathrm{x}}$} \\
\hline Untreated & 3,345 & 3,799 & 3,272 & 3,434 & 8 & 33 \\
\hline \multicolumn{7}{|c|}{ Shank-injected treatments } \\
\hline MB:Pic & 0 & 0 & 0 & 1 & 0 & 0 \\
\hline IM:Pic $67 / 33$ & 2 & 0 & 2 & 0 & 0 & 0 \\
\hline 1,3-D:Pic & 0 & 0 & 0 & 113 & 0 & 0 \\
\hline 1,3-D-shank & 2 & 0 & 1 & 3 & 0 & 1 \\
\hline \multicolumn{7}{|c|}{ Drip-applied treatments } \\
\hline IM:Pic $67 / 33$ & 2 & 4 & 3 & 271 & 0 & 2 \\
\hline 1,3-D:Pic-drip & 4 & 0 & 1,078 & 761 & 0 & 5 \\
\hline 1,3-D-drip & 345 & 141 & 576 & 1,710 & 0 & 3 \\
\hline LSD $(0.05)^{\mathrm{w}}$ & 564 & 830 & 1,121 & 1,393 & 4 & 10 \\
\hline
\end{tabular}

${ }^{\text {z }}$ Statistical analyses on nematode population was conducted on $\log$ transformed $[\ln (n+1)]$ data; however, data presented are the antilogs of the means.

"Treatments are detailed in Table 2. The 2004 trial included four treatments applied with tractor-mounted shankinjection equipment $(\mathrm{MB}: \mathrm{Pic}=98 \%$ methyl bromide: $2 \%$ chloropicrin at $400 \mathrm{lb} / \mathrm{acre}$; IM:Pic $67: 33=67 \%$ iodomethane:33\% chloropicrin at $300 \mathrm{lb} / \mathrm{acre}$; 1,3-D:Pic = 61\% 1,3-dichloropropene:35\% chloropicrin at $515 \mathrm{lb} /$ acre; 1,3-D-shank $=98 \%$ 1,3-dichloropropene at $332 \mathrm{lb} /$ acre $)$ and three treatments applied through a drip irrigation system (IM:Pic 67:33 = 67\% iodomethane:33\% chloropicrin at $300 \mathrm{lb} /$ acre; 1,3 -D:Pic-drip = 61\% 1,3dichloropropene:33\% chloropicrin at $515 \mathrm{lb} / \mathrm{acre} ; 1,3$-D-drip $=94 \% 1,3$-dichloropropene at $332 \mathrm{lb} / \mathrm{acre}$ ); $1 \mathrm{lb} /$ acre $=1.1209 \mathrm{~kg} \cdot \mathrm{ha}^{-1}$. All treatments were covered with high-density polyethylene (HDPE) tarp in 2004.

${ }^{x} 1$ inch $=2.54 \mathrm{~cm}, 1$ nematode $/ 100 \mathrm{~cm}^{3}=0.1639$ nematode $/$ inch $^{3}$

"Fisher's protected least significant difference procedure at $P<0.05$; NS $=$ nonsignificant.

trees compared with the control. Total cull trees ranged from 3.2 to 6.8 trees/plot but did not differ statistically among treatments (data not shown). Each cull tree was evaluated by personnel from the cooperating nursery and was categorized as double joint, no scion, twisted root/ stem, mechanical defect, root/cavity rot, crown/root gall, crooked top, one-sided root, forked root, torn root, few roots crooked roots, knobby, sunburn, or double trunk. No statistical differences were found among treatments for any of the cull categories with the exception of

Table 6. Weed control, preharvest trunk caliper measurements, and tree quality at harvest in a $2004-06$ nut tree nursery fumigation trial near Yuba City, CA. ${ }^{\mathrm{z}}$

\begin{tabular}{|c|c|c|c|c|c|c|c|c|}
\hline \multirow[b]{2}{*}{ Treatment $^{\mathrm{y}}$} & \multicolumn{3}{|c|}{ Weed population } & \multicolumn{5}{|c|}{ Marketable trees $^{\mathrm{x}}$} \\
\hline & $\begin{array}{l}\text { Bur- } \\
\text { clover }\end{array}$ & $\begin{array}{c}\begin{array}{c}\text { Volunteer } \\
\text { wheat }\end{array} \\
\end{array}$ & $\begin{array}{c}\text { Total } \\
\text { weeds }\end{array}$ & $\begin{array}{l}<1 / 4 \text { inch } \\
\text { diam }\end{array}$ & $\begin{array}{c}1 / 4 \text { to } 1 / 2 \text { inch } \\
\text { diam }\end{array}$ & $\begin{array}{c}1 / 2 \text { to } 5 / 8 \text { inch } \\
\text { diam }\end{array}$ & $\begin{array}{l}>5 / 8 \text { inch } \\
\text { diam }\end{array}$ & Total \\
\hline \multicolumn{9}{|c|}{ Shank-injected treatments } \\
\hline MB:Pic & 151 & 9 & 161 & 4.0 & 28.6 & 13.6 & 0.8 & 47.0 \\
\hline IM:Pic $67 / 33$ & 128 & 39 & 169 & 3.4 & 21.6 & 22.2 & 0.8 & 48.0 \\
\hline \multicolumn{9}{|c|}{ Drip-applied treatments } \\
\hline IM:Pic $67 / 33$ & 122 & 16 & 140 & 3.6 & 10.0 & 20.4 & 5.2 & 39.2 \\
\hline 1,3-D:Pic-drip & 112 & 22 & 137 & 3.4 & 16.8 & 24.4 & 2.6 & 47.2 \\
\hline 1,3-D-drip & 141 & 11 & 155 & 3.4 & 11.2 & 26.8 & 3.8 & 45.2 \\
\hline $\operatorname{LSD}(0.05)^{\mathrm{x}}$ & 50 & 36 & 55 & NS & 8.6 & 8.9 & NS & 6.4 \\
\hline
\end{tabular}

${ }^{2}$ Weed data collected were 2 Mar. 2005 and almond trees were harvested Jan. 2006.

'Treatments are detailed in Table 2. The 2004 trial included four treatments applied with tractor-mounted shank-injection equipment $(\mathrm{MB}$ :Pic $=98 \%$ methyl bromide:2\% chloropicrin at $400 \mathrm{lb} /$ acre; IM:Pic $67: 33=67 \%$ iodomethane:33\% chloropicrin at $300 \mathrm{lb} /$ acre; 1,3 -D:Pic = 61\% 1,3-dichloropropene:35\% chloropicrin at $515 \mathrm{lb} /$ acre; 1,3 $\mathrm{D}$-shank $=98 \% 1,3$-dichloropropene at $332 \mathrm{lb} /$ acre) and three treatments applied through a drip irrigation system (IM:Pic $67: 33=67 \%$ iodomethane:33\% chloropicrin at 300

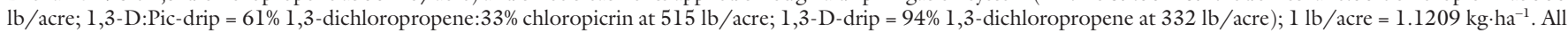
treatments were covered with high-density polyethylene (HDPE) tarp in 2004

${ }^{x} 1$ inch $=2.54 \mathrm{~cm}$, l plant $/ 50 \mathrm{ft}=0.0656$ plant $/ \mathrm{m}$.

"Fisher's protected least significant difference procedure at $P<0.05$; Ns = nonsignificant. 
crown/root gall. Three of five replicates of the drip-applied IM:Pic 67/ 33 treatment had one or two trees culled due to crown/root gall, which was more than all other treatments.

In summary, combinations of IM and Pic provided similar pest control to MB:Pic, although shankinjected IM:Pic was more consistent than drip-applications. By contrast, drip-applied 1,3-D/Pic performed better than shank-injected 1,3-D:Pic at shallow depths, especially when the drip-application was compared with the untarped 1,3-D:Pic treatment in the garden rose trial. Nematode control at the end of the cropping cycle was statistically similar to MB:Pic with all treatments in both experiments; however, detectable populations were found in many of the drip-applied treatments. These results suggest that drip-applications in open-field nurseries may not consistently provide sufficient nematode control for state certification, particularly in fields with finer soil texture such as the clay loam in the nut tree nursery trial.

It is important to note that most of the soil in the surface 12 inches was above the drip tubes (installed at 810 inches) used to deliver the fumigants. Wang and Yates (1999) found that drip application of $1,3-\mathrm{D}$ at an 8 -inch depth resulted in more 1,3-D remaining in the soil $1.4 \mathrm{~d}$ after treatment than application at the 1 -inch depth, probably due to emission at the soil surface. The preferential movement downward, coupled with greater emissions at the soil surface and potential dilution due to the water cap, could account for the reduced efficacy above the drip tape for some treatments. Reduced efficacy at the deepest soil depths could be a result of insufficient water to deliver the material to the deepest depths in the case of drip-applied treatments or insufficient rate of fumigant to deliver an effective concentration of fumigant to the deepest depths for the specific soil conditions present at the time of fumigation (Gao et al., 2008).

Some treatments in the garden rose trial, such as tarped 1,3-D:Pic, had detectable root-knot in only one of the six replications (data not shown). This suggests there could have been a minor application problem, or possibly contamination from another sample. Because root-knot was only detected in three of the six untreated plots, it is clear that the distribution of root-knot nematode in this field was very patchy. In our experience, this is not unusual for root-knot nematode, especially at the low population levels commonly found in nursery fields that have been fumigated at the start of each nursery crop cycle. These data demonstrate that the untarped 1,3-D:Pic, low rates of Pic, and the metam sodium treatments did not provide adequate nematode control in this field for a nursery crop. Although drip-applied metam sodium has been reported to provide acceptable nematode control in carrot (Daucus carota) and tomato (Solanum lycopersicum) cropping systems, other articles report inadequate nematode control (Overman, 1982; Overman et al., 1987; Roberts et al., 1988).

The lack of consistent control conveys a high risk to growers of high-value nursery crops. A critical difference between annual fruit or vegetable cropping systems and field nurseries is the "pathogen-free" requirement for clean planting stock. The level of nematode control needed to achieve a productive tomato crop is not sufficient to produce a pathogenfree nursery stock. For treatments other than untarped 1,3-D:Pic and metam sodium, it is impossible to be certain whether low to undetectable nematode populations are due to acceptable nematode control or to the lack of a nematode population before treatment in those plots.

The historical use of $\mathrm{MB}$ in each nursery crop cycle has made it difficult to find nursery fields with sufficient pest, pathogen, and weed pressure to provide a robust test of potential $\mathrm{MB}$ alternatives. Problems such as nutsedges (Cyperus spp.) that have been controlled by $\mathrm{MB}$ are becoming more common as growers transition to alternative fumigants. This illustrates the need to evaluate alternatives over multiple cropping cycles after the residual effects of long-term use of $\mathrm{MB}$ in field nurseries has dissipated.

Plastic tarps are an additional expense but can improve efficacy of weed and pest control in the upper soil layers by slowing emission rates and increasing exposure time. Purchase, placement, removal, and disposal of standard HDPE tarpaulins cost about $\$ 900 /$ acre in California. Economic analyses are needed to determine whether use of a plastic tarp with $\mathrm{MB}$ alternatives is cost effective in open-field perennial nursery cropping systems. Low permeability films, such as virtually impermeable films (VIF), have been reported to retain some materials in the soil for a longer period, allowing efficacy to be maintained while using a lower rate of chemical (Gamliel et al., 1997; Noling et al., 2005). Currently, the low permeability films cannot legally be used in California with $\mathrm{MB}$ and were not included in these trials.

Finally, shank-injected IM:Pic and drip-applied 1,3-D:Pic performed well in the studies described here. If IM becomes available to growers in California, additional trials with IM:Pic are needed to determine the optimal balance between rate and formulation (proportion of iodomethane to chloropicrin and drip- versus shank-application) for specific plant types and varieties. Additional, larger open-field nursery trials with 1,3D:Pic and IM:Pic are needed to accumulate the foundation of knowledge and experience to assist growers in transitioning away from $\mathrm{MB}$ while continuing to produce pest- and pathogen-free nursery stock. Potential MB alternatives must be demonstrated to be consistently, technically, and economically feasible management strategies over the range of conditions occurring in commercial nursery production systems before it can reasonably be expected that growers will adopt these alternatives.

\section{Literature cited}

Ajwa, H.A. and T. Trout. 2004. Drip application of alternative fumigants to methyl bromide for strawberry production. HortScience 39:1707-1715.

Ajwa, H.A., T. Trout, J. Mueller, S. Wilhelm, S.D. Nelson, R. Soppe, and D. Shatley. 2002. Application of alternative fumigants through drip irrigation systems. Phytopathology 92:1349-1355.

Barker, K.R. 1985. Nematode extraction and bioassays, p. 19-35. In: K.R. Barker, C.C. Carter, and J.N. Sasser (eds.). An advanced treatise on Meloidogyne volume II: Methodology. North Carolina State University Graphics, Raleigh, NC.

Becker, J.O., H.D. Ohr, N.M. Grech, and M.E. McGiffen, Jr., and J.J. Sims, 1998. Evaluation of methyl iodide as a soil fumigant in container and small field plot studies. Pestic. Sci. 52:58-62. 
California Department of Food and Agriculture. 2002. Approved treatment and handling procedures to ensure against nematode pest infestation of nursery stock. Nursery Inspection Procedures Manual, Item \#7. 17 Nov. 2008. <http:// www.cdfa.ca.gov/phpps/PE/Nursery/ pdfs/NIPM_7.pdf>.

California Department of Pesticide Regulation. 2002. California management plan: 1,3Dichloropropene. 17 Nov. 2008. <http:// www.cdpr.ca.gov/docs/emon/methbrom/ telone/mgmtplan.pdfs.

De Cal, A., A. Martinez-Treceno, J.M. Lopez-Aranda, and P. Melgarejo. 2004. Chemical alternatives to methyl bromide in Spanish strawberry nurseries. Plant Dis. $88: 210-214$

Dreistadt, S.H. 2001. Diseases, p. 69130. In: M.L. Flint (ed.). Integrated pest management for floriculture and nurseries. Publication 3402. University of California, Oakland, CA.

Duniway, J.M. 2002. Status of chemical alternatives to methyl bromide for preplant fumigation of soil. Phytopathology 92:1337-1343.

Eayre, C.G., J.J. Sims, H.D. Ohr, and B. Mackey. 2000. Evaluation of methyl iodide for control of peach replant disorder. Plant Dis. 84:1177-1179.

Flegg, F.F.M. and D.F. Hooper. 1970. Laboratory methods for work with plant and soil nematodes, p. 5-22. In: J.F. Southey (ed.). Tech. Bul. 2. Ministry of Agriculture, Fish and Food, London.

Gamliel, A., A. Grinstein, Y. Peretz, L. Klein, A. Nachmias, L. Tsror, L. Livescu, and J. Katan. 1997. Reduced dosage of methyl bromide for controlling verticillium wilt of potato in experimental and commercial plots. Plant Dis. 81:469474.

Gao, S., T.J. Trout, and S. Schneider. 2008. Evaluation of fumigation and surface seal methods on fumigant emissions in an orchard replant field. J. Environ. Qual. 37:369-377.

Gerik, J.S. 2005. Drip-applied soil fumigation for freesia production. HortTechnology 15:820-824.

Gilreath, J., B. Santos, T. Motis, J. Noling, and J. Mirusso. 2005. Methyl bromide alternatives for nematode and Cyperus control in bell pepper (Capsicum annuиm). Crop Prot. 24:903-908.

Hanson, B.D. and S.A. Schneider. 2008. Evaluation of weed control and crop safety with herbicides in open field tree nurseries. Weed Technol. 22:493-498.

Horowitz, M. and R.B. Taylorson. 1985. Behavior of hard and permeable seeds of Abutilon theophrasti Medic. (velvetleaf). Weed Res. 25:363-372.

Huisman, O.C. and L.J. Ashworth, Jr. 1974. Quantitative assessment of Verticillium albo-atrum in field soils: Procedural and substrate improvements. Phytopathology 64:1043-1044.

Jenkins, W.R. 1964. A rapid centrifugalflotation technique for separating nematodes from soil. Plant Dis. Rptr. 48:692.

Johnson, D.E., B. Lear, S.T. Miyagawa, and R.H. Sciaroni. 1969. Multiple applications of 1,2-dibromo-3-chloropropane for control of nematodes in established rose plantings. Plant Dis. Reptr. 53:34-37.

Karlik, J.F., J.O. Becker, and U.K. Schuch. 2001. IPM for field-grown rose plants in California. Acta Hort. 547:97-102.

Lampinen, B., G. Browne, S. Schneider, A. Shrestha, B. Holtz, and L. Simon. 2005. Alternative pre-plant soil fumigation treatments for deciduous tree crops, Proc. Annu. Intl. Res. Conf. on Methyl Bromide Alternatives and Emissions Reductions. p. 44-1 to 44-6.

Mann, R., S. Mattner, R. Gounder, R. Brett, and I. Porter. 2005. Evaluating novel soil fumigants for Australian horticulture, Proc. Annu. Intl. Res. Conf. on Methyl Bromide Alternatives and Emissions Reductions. p. 34-1 to 34-4.

Martin, F.N. 1992. The genus Pythium, p. 39-49. In: L.L. Singleton, J.D. Mihail, and C.M. Rush (eds.). Methods for research on soil borne phytopathogenic fungi. American Phytopathological Society, St. Paul, MN.

Martin, F.N. 2003. Development of alternative strategies for management of soilborne pathogens currently controlled with methyl bromide. Annu. Rev. Phytopathol. 41:325-350.

Motis, T.N. and J.P. Gilreath. 2002. Stimulation of nutsedge emergence with chloropicrin, Proc. Annu. Intl. Res. Conf. on Methyl Bromide Alternatives and Emissions Reductions. p. 7-1 to 7-2.

Noe, J.P. 1985. Analysis and interpretations of data from nematological experiments, p. 187-196. In: K.R. Barker, C.C. Carter, and J.N. Sasser (eds.). An advanced treatise on Meloidogyne, Volume 2: Methodology. North Carolina State University Graphics, Raleigh, NC.
Noling, J., C. Chandler, and J. Gilreath. 2005. Commercial field evaluations of methyl bromide alternatives in Florida strawberry, Proc. Annu. Intl. Res. Conf. on Methyl Bromide Alternatives and Emissions Reductions. p. 8-1 to 8-5.

Overman, A.J. 1982. Soil fumigation via drip irrigation under full-bed mulch culture for row crops. Proc. Soil Crop Sci. Soc. Florida 41:153-155.

Overman, A.J., A.A. Csizinszky, J.P. Jones, and C.D. Stanley. 1987. Efficacy of metam sodium applied via drip irrigation on tomato. Proc. Soil Crop Sci. Soc. Florida 46:4-7.

Roberts, P.A., A.C. Magyarosy, W.C. Matthews, and D.M. May. 1988. Effects of metam sodium applied by drip irrigation on root-knot nematodes, Pythium ultimum, and Fusarium sp. in soil and on carrot and tomato roots. Plant Dis. 72:213-217.

Santo, G.S. and B. Lear. 1976. Influence of Pratylenchus vulnus and Meloidogyne hapla on the growth of rootstocks of rose. J. Nematol. 8:18-23.

Schneider, S., T. Trout, J. Gerik, A. Shrestha, and R. Rodriquez-Kabana. 2005. Methyl bromide alternatives for perennial crop-field nurseries, Proc. Annu. Intl. Res. Conf. on Methyl Bromide Alternatives and Emissions Reductions. p. $41-1$ to $41-4$.

Schneider, S.M., T. Trout, J. Gerik, and H. Ajwa. 2004. Perennial crop nurseries: performance of methyl bromide alternatives in the field, Proc. Annu. Intl. Res. Conf. on Methyl Bromide Alternatives and Emissions Reductions. p. 29-1 to 29-4.

United Nations Environment Programme. 1999. The Montreal Protocol on substances that deplete the ozone layer as adjusted and amended in London 1990, Copenhagen 1992, Vienna 1995, Montreal 1997, Beijing 1999. 17 Nov. 2008. <http://ozone.unep. org/Publications/MP_Handbook/ Section_1.1_The_Montreal_Protocol>.

Voisin, R., J.C. Minot, D. Esmenjaud, Y. Jacob, G. Pelloli, and S. Aloisi. 1995. Host suitability of rose rootstocks to the root-knot nematode Meloidogyne hapla using a high-inoculum-pressure test. Acta Hort. 424:237-239.

Wang, D. and S.R. Yates. 1999. Spatial and temporal distributions of 1,3 dichloropropene in soil under drip and shank application and implications for pest control efficacy using concentration-time index. Pestic. Sci. 55:154-160. 